\title{
CONCEPTUALISING SOCIAL HEALTH OF THE RUSSIAN YOUNG FAMILY AND MODELS OF PARENTAL BEHAVIOUR IN A RISK SOCIETY
}

\section{Zakharova Tatyana Yunalyevna \\ Gafiatulina Natalya Halilovna \\ Artamonova Yana Viktorovna}

\author{
Master of Arts (School of Education) candidate, University of East Anglia (UEA), \\ Norwich Research Park, Norwich NR4 7TJ, the UK. \\ E-mail: T.zakharova@uea.ac.uk \\ Candidate of sociological science, associate professor of chair of modeling of social \\ processes, Southern Federal University (160, Pushkinskaya str., Rostov-on-Don, \\ 344006, Russian Federation). E-mail: gafiatulina@yandex.ru \\ Candidate of sociological sciences, Instructor of the Institute of Sociology and Regional \\ Studies, Southern Federal University (160, Pushkinskaya str., Rostov-on-Don, 344006, \\ Russian Federation). E-mail: janaserduchenko@mail.ru
}

\begin{abstract}
A young family is one of the key concepts of youth sociology and family sociology raising the problems of social health and parental behaviour. This article provides an overview of a Russian young family as a phenomenon from a sociological perspective and analyses models of parental behaviour in the context of social health formation. The authors of this article also present a layered assessment of the social health of a young family. The social health of a young family is considered as well-being in terms of primary family socialisation, marital and parent-child relationships, a system of socialisation of family values and preferences, ethical and moral norms of family society, and also young parents' attitudes to their children. The authors of this article conclude that the risks existing in society affect a young Russian family which cannot effectively fulfil its socialisation functions and positively influence the development of new generations.
\end{abstract}

Keywords: Russian young family, social health, models of parental behaviour, youth, marital relations, parentchild relationships, risk society, types of young families, socialisation, state family policy.

Over the last decades, different organisations and researchers around the world attract attention to a concept of family and conditions in which its members are born and live and which affect parents' and children's health [1]. By health, we mean "a state of complete physical, mental, and social well-being and not merely the absence of disease or infirmity" [2, p. 1].

In the context of Russia, human sciences, socio-economic and social fields of research studies raise the problem of the social health of Russian youth in general and Russian young family in particular among the most important tasks of youth sociology and family sociology [3].

Undoubtedly, a family is one of the most important institutional elements, which is especially necessary for both the individual life and health of each of the family members and the development of Russian society as a whole. A young family is considered one of the most socially vulnerable and unprotected groups of the population which is rightfully classified by many researchers as a social risk group [4].

Therefore, the main goal of state family policy regarding a young family as a subject of the social structure in the Russian risk-prone society is to create appropriate conditions for maintaining and developing young family social well-being (social health, according to the concept of the World Health Organization) or subjective well-being, cultivating family values, strengthening family lifestyles, and an implementation of all the functions assigned to the young family.

Subjective well-being along with risks and coping strategies [1, p. 1118] significantly affects family formation and existence. Subjective well-being is believed to consist of economic status, social capital, capabilities and health [ibid.]. Hence, the overall prosperity of young families acts as the basis for social health. However, unfortunately, according to experts, a new modern generation of young Russian families is characterised by a decrease in the level of physical, mental and social health, as well as intellectual and spiritualmoral potential [5].

The way out of this crisis tends to be further support of a Russian young family in both state and society, as a result of which Russian young families could receive necessary conditions for healthy, full-fledged socialisation and successful fulfilment of their social functions and reproductive expectations [6].

\section{Interpretation of a 'young family'}

To determine the concept of a young family, we appeal to the Russian Federation decree of the Government from December 29, 2007. No. 865 "On amendments to acts of the Government of the Russian Federation on the implementation of measures to provide housing for young families". According to this document, a young family is a family which is "up to 3 years after marriage (if a family has children, there is no limit on marriage duration), provided that one of the spouses has not reached the age of 35" [7]. 
Therefore, the legislatively established features of a Russian young family include at least three characteristics: a registered marriage union of young people aging between 18 and 35 years old and being married for up to 3 years. Besides, a family with only one parent under the age of 30-35 years old having a juvenile is also considered a young family.

Next, a young family is a special type of family that differs from other types of a family as the quality of family relations in it is determined by marital relations, and not by kinship and parenthood. Moreover, even the presence of a child does not eliminate the dominance of marital relations over parental relations. Hence, there is a necessity to consider the types of young families that are usually distinguished.

We utilised a classification of the Russian familist V.S. Torokhtiy [8, p. 127], who singled out the following three types of a young family:

The first type is traditional. Families of this type are characterised by the orientation of young spouses solely on family values and typically on a two-child family. Formally, the husband is the head of the family. However, a family's leadership is largely determined by behaviour in the household sector (finance and lifestyle). Leisure most often is joint and closed, a circle of friends is usually limited, and this kind of family also can temporarily concentrate only on family affairs.

The second type of a young family is mainly focused on the development of the personality of the husband and wife with an inclination toward a small family. A social-role balance is observed (if possible, the help of the parents of the spouses is used). The type of leadership is determined by the spheres of family life and based on democratic relationships.

The third type of young family is focused mainly on the entertainment of young spouses. Husband and wife have both mutual friends and their own friends from their former surroundings. Family leadership can be both authoritarian and democratic, and this type of family is characterised by the preference to be a childless or small family [8].

A favourable type for the social health formations are such young families, which are focused mainly on the development of personality, where there is complete mutual understanding in family relations between young parents, a style of communication is democratic, and parents have a high level of education, general culture, and pedagogical preparedness.

According to many authors, there is a close relationship between the formation of each type of young family and other social processes such as demographic changes in society, socio-economic and social stability, the nature and orientation of migration processes, as well as social and psychophysiological health.

Speaking about the social health of a young family, it is important to take into account that young families in its process of development experience difficulties which inevitably affect their social health. As stated in the article by A.D. Plotnikov on the comprehension of a young family, particularly a young family with young children is in dire need of special food and clothing, parental and state care for strengthening physical, mental and social health and a special education system [9, p. 201] and the formation of certain models of parenthood (parental behaviour).

It is for this reason that a young family, parenthood and childhood are the key objects of social policy since the social health of the whole society largely depends on the well-being of the Russian young family. Any young family is the key to the stability of the whole society. In the family, each person gets "a ticket to life"; the family determines the values of this life and, in the aggregate, the organisation of family life in society fundamentally affects the nature of the development of society itself, its demographic indicators, the development of the personal and professional spheres, etc. [10].

Since the social health of youngest families and younger generations is the result of the process of family socialisation, it is necessary to consider the existing crisis of the socialisation mechanisms of the family. Presently, the socialisation of young generations of Russians proceeds in difficult conditions associated with the long transformation of the post-Soviet Russian society, accompanied by anomie processes, a crisis of the main institutions of socialisation, and primarily, the institution of the family. It is not a secret that the result of a healthy, harmonious socialisation of the young generation is the formation of its social health. At the same time, we would like to clarify that the social health of the young generation is formed on the basis of the socialisation mechanisms of biological and psychosocial genesis [11, p. 178].

By social health of a young family, we understand the well-being, considered in terms of primary family socialisation, marital and child-parent relations, a system of socialisation of family values and preferences, ethical and moral norms of family society, as well as a reflection of the attitude of young parents to their young children.

Furthermore, it is possible to subdivide types of social health according to its levels: successful, problematic, conflict and crisis young families; which we will discuss more thorough later in the discussion of the models of parental behaviour of a young family in a modern risk society. 
Finally, there are many factors which influence social health of a family such as structural, functional (family composition, family education style), socio-psychological (socio-psychological climate of the family and family interaction style) and individual psychological (socio-psychological characteristics of parents and children, especially family values) ones. The norm or deviation from the norm in the health of family members adequately affects the social health of not only the individual but as a result the sociopsychological health of the family as a whole [12, p. 14]. For this reason, assessing the social health of a young family we can define three positions [13]:

- The norm of social health of a family conditionally means the development of individual sociopsychological phenomena and their consistency with the needs of other family members and the presence of social (intra-family) activity;

- A deviation from the norm in the social health of a young family is characterised by inconsistency in meeting the needs of each family member, as well as a partial lack of social (intra-family) activity. This is typical for families in need of social and psychological counselling;

- The lack of social health of the family is manifested in intra-family discomfort and partial autonomy of the actions of its members to meet purely individual needs.

In conclusion, we shall say that the obstacles preventing social well-being and health are believed to be coped with coping strategies. The concept of coping strategies is based on Aaron Antonovsky's theory (Antonovsky, 1979) of the sense of coherence [1]. Antonovsky observed other people coping with their everyday problems and then argued that an attitude towards life, which matures over the life course, defines how people cope with their problems. Also, Antonovsky divided coping strategies into two groups: inner (physical and psychological nature of people) and external (education, society, employment) coping strategies. From this point of view, we argue that young families are not mature enough to have developed coping strategies and they specifically need additional support.

\section{Parental Behaviour}

The results of L.A. Gritsay studies among young families have identified five basic models of parental behaviour: parenthood, preserving the remnants of tradition; "Split" parenthood; deviant parental behaviour; "Individualistic" parenthood and creative parental behaviour [14, p. 188].

The first model of parental behaviour in a young family is based on the partial preservation of traditional parental attitudes regarding the birth and upbringing of children and, in general, characterised by a successful parenting experience. Due to its focus on the traditional perception of parenthood, learned from the experience gained in their parental families in the current situation of social risk and moral instability, the modern young family is becoming quite vulnerable to the challenges, threats, and risks of the global socioeconomic space, which affects the social Family Health.

The adaptation process of such a model of the Russian young family is significantly complicated because each of the young and still inexperienced spouses brings the experience of their parental family, spousal relations of parents and child-parent relations. Therefore, in such a family two "psychologies" of young people quite often clash and intertwine: the "psychology" of the family where the husband grew up, and the "psychology" of the parental family of the young wife. These two often multidirectional and controversial "psychologies" are reflected in the social health of the young family, since there is a conflict interaction in these families.

The second model of "split" parenthood is typical, as a rule, for single-parent families in which only one parent is engaged in raising children, combining the functions of both father and mother, which does not pass without a trace for the formation of the child's personality and social health.

The third model of parental behaviour in a young family is presented as a deviant model. By its name alone, it can be defined as the source of a dysfunctional and problematic young family since in such families young parents lead an asocial lifestyle, and young children are without supervision and proper care, which does not correspond to the concept of good social health.

The fourth model of parental behaviour of a young family is individualistic and characterised by the manifestation of relations between parents and children of two types - partner or authoritarian. In both cases, according to L.A. Gritsay, this model is characterised by the alienation of family members from each other [14].

In the first case, due to free education, the emphasis is put on the moral independence of children from parents, and in the second case, due to the authoritarianism of parents and the suppression of children's will, the emphasis is put on their transformation into dependent individuals. Such families can be considered "critical". Hence, what kind of ensuring a high level of social health can be discussed in this case?

The fifth model of parenthood of a young family is constructive (i.e., prosperous), and according to its author, L.A. Gritsay, this is the most effective model. This is explained by the fact that this model is based on a solid worldview attitude that corresponds to the spiritual and moral heritage of Russia and its family 
values. Agreeing that a strong value and spiritual-moral "platform" is necessary for the formation of a socially, mentally and physically healthy person, we would like to note that in modern Russia this model of parental behaviour cannot be explicated as really functioning since this platform itself is presently missing.

Russia seems to have lost common value and spiritual-moral foundations, and, consequently, its socialisation space does not contain the basic, integral and shared by all socialisation agents value-normative family foundations. In this regard, we are forced to state that the fifth model of parenthood can be considered as an ideal model, which, perhaps, should be guided, and it seems necessary to restore the integral spiritual and moral space of Russian society and the socialisation system that was destroyed during the years of post-Soviet transformations.

In this context, relying on the selected models of parental behaviour, the conventionality of which is determined by any attempt to classify the phenomena and processes studied, we can say that the most effective (creative) model is currently not functional in Russian reality. It is also worth agreeing that the parenting model is more widespread in Russia, preserving traditional trends of deviant and individualistic families with the corresponding parenting models.

On this basis, it can be assumed that safe parenting in Russia, as a reflection of the dominant model of parenthood with traditional characteristics, still retains the status of dominant.

It should also be noted that a high level of satisfaction with family life, parent-child relationships, and a positive assessment by parents of the future of young generations are not typical for most Russians. Today, Russian young families are worried about numerous problems. Among the main problems are: unsatisfactory material base (economic well-being) of a young family, housing problems, issues of spiritual and moral relations in a young family, lack of reproductive attitude or restriction of birth of children, negative evaluation of their family's future, etc. problems, then we can talk about the crisis of the institution of the family, problems of socialisation, and, therefore, about the unsatisfactory level of social health of the young family.

A special place in our work is occupied by the problem of employment of young spouses, who belong to the social group - "youth". In this regard, the situation of the employment of young spouses, in general, is affected by regional labour market difficulties they may face in finding a job. The period of pursuing education, which is lengthening in the period, delays the moment for young people to enter full-fledged working life and achieve professional maturity, and at the same time, the moment of financial independence and material well-being of a young family is delayed [15, p. 21].

Furthermore, young people aged 18-24 are students completing their vocational training after which they become the most vulnerable group entering the Russian labour market, as they still lack professional and social experience and, as a result, are less competitive.

At the age of 21-24, the majority of Russian youth experiences the so-called "shock from reality" because their ideal ideas about future work activities conflict with the real situation in the workplace. Special adaptation youth programs are designed to help young employees adequately perceive the state of affairs existing in the social sphere and labour market. T.S. Zubkova draws attention to the following fact that the low salary of a young specialist, especially in the public sector, and dissatisfaction with secondary earnings push young professionals to look for work in another city and go abroad, which impedes the strengthening of a young family and does not contribute to its social health [16, p. 118].

Moreover, traditional and "split" parental behaviour families, like young married women with or without a child, may have additional employment problems. Admission to work may be refused due to fears that the potential employee will either soon go on parental leave or will devote more time and energy to the family and the child, but not to perform professional duties.

Finally, it is critically important to consider psychological unpreparedness for marriage which is especially the case for the first four models of parental behaviour we described. If a young couple is more or less financially dependent on their elders, then the possibility of control or punishment is directly dependent on the length of their financial dependency. This situation leads to a violation of the boundaries of a young family and a change or even complete disappearance of the rules for the functioning of a young family which leads to a violation of emotional interaction, tension and a feeling of general dissatisfaction with marriage which can become the evidence of "ill" social health of a young family.

The problem of marital conflicts also affects the social health of the young family. Conflictogenicity, as a factor negatively affecting the level of social health of a young family, is especially acute and is considered by researchers separately in the context of psychology and conflictology. According to L.B. Schneider, for the stage after the birth of a child it is characteristic to have separation of roles associated with paternity and motherhood, coordination between spouses, material support of new family living conditions, adaptation to great physical and psychological stress, and limiting the total activity of spouses outside the family [17, p. 259]. 
Thus, the modern young family, unfortunately, cannot effectively fulfil its socialisation functions and positively influence the development of new generations. Unfortunately, the negative potential of such a family has long-term trends that can be expressed in the social "ill" health of the family, in particular, and the threat to the safety of society as a whole [18].

That is why a young family, marital and child-parent relations, parenthood and childhood must certainly become key objects of state family policy since the social health of the whole society depends on the wellbeing of a young family. In this regard, our common work should be directed towards:

- restoration of the status of a young family as the main institution of primary socialisation;

- formation of the potential of a young family and its social health, taking into account its characteristics, values, and traditions;

- restoration and reconsideration of the spiritual, moral and educational-socialisation opportunities of young families of different types and different models of parental behaviour;

- stabilisation and improvement of housing conditions and socio-economic situation of a young family, reduction of the potential for conflict in it, creation of a positive socio-psychological climate and an atmosphere of well-being through social protection and social work with young families.

The use of modern methods and technologies of social work with young families should help to improve the quality of social protection of spouses, create a sense of security in the family, and improve the quality of life in general, which will contribute to the formation and preservation of the social health of the young family.

\section{References}

1. Russel L.T., Coleman M., and Ganong L. Conceptualizing Family Structure in a Social Determinants of Health Framework. 2018. C. 735-748.

2. World Health Organization. Constitution of the World Health Organization: Basic documents, 2007, (46th ed.).

3. Верещагина А.В., Гафиатулина Н.X. Благополучное детство как основа социального здоровья молодых поколений: индикаторы социологического измерения [Электронный ресурс] // Инженерный вестник Дона. 2016. №1. ivdon.ru/ru/magazine/archive/n1y2016/3527.

4. Кузьменко Н.И. Молодая семья как семья категории группы риска / Молодежь в современном обществе. Магнитогорск, 2015. С. 154-157.

5. Vaskov M., Rezvanov A., Kasyanov $V$., et al., VALUE ORIENTATIONS OF RUSSIAN YOUTH IN THE SYSTEM OF MANAGING THE MORAL SECURITY OF SOCIETY. Вісник Національної академії керівних кадрів культури і мистецтв. 2018. № 2. С. 134-140.

6. Сердюченко Я.В. Формирование ценностных установок молодой семьи в условиях трансформации российского общества / В сборнике: Сборник материалов IV Южно-Российского политологического конвента IV Всероссийская (с международным участием) конференция студентов, аспирантов и молодых ученых в рамках Южно-Российского политологического конвента. 2013. С. 367-370.

7. Постановление Правительства РФ от 31 декабря 2005 г. № 865.

8. Торохтий B.C. Основы психолого-педагогического обеспечения социальной работы с семьей. Часть 1. М.: МГСУ, 2000. $240 \mathrm{c.}$

9. Плотников А.Д. Молодая семья // Знание. Понимание. Умение. 2006. №3. С. 201 - 202.

10.Глузман Н.А., Горбунова Н.В., Фоминых Н.Ю. Педагогическое проектирование личностно-профессионального маршрута будущего учителя: монография. Севастополь: РИБЭСТ, 2015. 303 с.

11.Гафиатулина H.X. Состояние институциональных субъектов, моделирующих социальное здоровье российской молодежи [Электронный ресурс] // Инженерный вестник Дона. 2014. №1. URL: ivdon.ru/magazine/archive/n1y2014/2296 (дата обращения 10.07.2016).

12.Рыбак Е.В., Слепцова Н.Г., Федулова А.Б., Цихончик Н.В. Молодая семья в современном обществе. М.: ООО «ТР-Принт», 2016. 150 с.

13.Меркульева Н.В. Современные подходы к диагностике психологического здоровья семьи [Электронный ресурc]. URL: www.rusnauka.com/12_KPSN_2014/Psihologia/12_167659.doc.htm (дата обращения 28.12.2015).

14.Грицай Л.А. Социальное измерение современного российского родительства // Вестник Института социологии. 2001. № 2. С. 187-201.

15.Зуйкова Е.М., Кузнецова Н.В. Молодая семья. М., 2004. 109 с.

16.Зубкова T.C., Тимошина Н.B. Организация и содержание работы по социальной защите женщин, детей и семьи. М., 2003. 128 с.

17.Шнейдер Л.Б. Психология семейных отношений. Курс лекций. М.: Апрель-Пресс, Изд-во ЭКСМО-Пресс, 2000. $512 \mathrm{c}$.

18.Свечкарев В.П., Сердюченко Я.В. Адаптивные модели преодоления рисков жизненного мира молодой семьи // Инженерный Вестник Дона. 2018. № 3. 
Захарова Татьяна Юнальевна, магистрант Университета Восточной Англии, Норвич (Norwich Research Park, Norwich NR4 7TJ, Великобритания). E-mail: T.zakharova@uea.ac.uk

Гафиатулина Наталья Халиловна, кандидат социологических наук, доцент, докторант кафедры моделирования социальных процессов, Институт социологии и регионоведения Южного федерального университета (344006, Россия, г. Ростов-на-Дону, ул. Пушкинская, 160). E-mail: gafiatulina@yandex.ru

Артамонова Яна Викторовна, кандидат социологических наук, преподаватель, Институт социологии и регионоведения Южного федерального университета (344006, Россия, г. Ростов-на-Дону, ул. Пушкинская, 160). E-mail: janaserduchenko@mail.ru

\section{СОЦИАЛЬНОЕ ЗДОРОВЬЕ РОССИЙСКОЙ МОЛОДОЙ СЕМЬИ И МОДЕЛИ РОДИТЕЛЬСКОГО ПОВЕДЕНИЯ В ОБЩЕСТВЕ РИСКА Аннотация}

В представленной статье в социологическом ракурсе анализируется российская молодая семья, рассматриваются модели родительского поведения в контексте формирования социального здоровья молодой семьи. Авторы статьи дают поуровневую оценку социального здоровья молодой семьи. Социальное здоровье молодой семьи рассматривается в качестве благополучия в аспекте первичной семейной социализации, супружеских и детско-родительских отношений, системы социализационных семейных ценностей и предпочтений, этических и нравственных норм семейного социума, а также отражение отношения молодых родителей к своим детям. Авторы статьи делают вывод, что российская молодая семья в связи с существующими в обществе рисками не может эффективно выполнять свои социализационные функции и оказывать положительное влияние на развитие новых поколений.

Ключевые слова: российская молодая семья, социальное здоровье, модели родительского поведения, молодежь, супружеские отношения, детско-родительские отношения, общество риска, типы молодой семьи, социализация, государственная семейная политика.

\section{THE DUAL ROLE OF “\#FIREME” IN CIVIL SERVANTS COMMUNICATOIN}

$\begin{array}{ll}\begin{array}{l}\text { Kotova } \\ \text { Nina }\end{array} & \begin{array}{l}\text { Doctor of Philology, Prof., Candidate of Philosophical Sciences, Head of Cathedra of Foreign } \\ \text { languages and speech communication, South-Russia Institute of Management - branch of } \\ \text { Russian Presidential Academy of National Economy and Public Administration } \\ \text { (70/54, Pushkinskaya St., Rostov-on-Don, 344002, Russian Federation), Prof. of Cathedr } \\ \text { of Developmental psychology (115/42, Bolshaya Sadovaya St., Rostov-on-Don, 344006, } \\ \text { Russian Federation). E-mail: ninakotova@mail.ru }\end{array} \\ \text { Kravtsova } & \text { Candidate of Philological Sciences, Associate Prof. of Cathedra of Foreign languages and } \\ \text { Viktoria } & \text { speech communication, South-Russia Institute of Management - branch of Russian } \\ \text { Yurievna } & \begin{array}{l}\text { Presidential Academy of National Economy and Public Administration (70/54, } \\ \text { Pushkinskaya St., Rostov-on-Don, 344002, Russian Federation); Senior Lecturer of }\end{array} \\ & \begin{array}{l}\text { the Department of Foreign Languages, Rostov Branch of the Russian Customs Academy } \\ \text { (20,Ave. Budennovsky, Rostov-on-Don, 344002, Russian Federation). }\end{array} \\ \text { Kotov } & \text { E-mail: inyaz@uriu.ranepa.ru } \\ \text { Grigory } & \text { Magistrate of the Academy of Psychology and Pedagogics, Southern Federal University } \\ \text { Sergeevich } & \text { (105/42, Bolshaya Sadovaya str., Rostov-on-Don, 344002, Russian Federation). } \\ & \text { E-mail: inyaz@uriu.ranepa.ru }\end{array}$

\section{Abstract}

Today it is generally accepted that one of the basic relationships is trust. In our view, respect as a meaning formed in the communication context has the same importance. An important area in which the majority of respondents are acutely aware of the lack of mutual respect is interaction with the authorities and the state government. The language competences of a civil servant in this work are considered from the perspective of examining the meaning of public statements in the context of discussing a particular issue.

Keywords: mutual respect, disrespect, social group, interpersonal relations, polling, discourse-analysis, government, self-control, discourse, dehumanization.

The classics of sociology paid little attention to the problems of mutual respect in social relations, although they explored categories that had an indirect relation to it: prestige, authority, symbolic capital, trust, etc. T. Parsons mentions mutual respect in the context of the research of the social community and the symbolic factors of consolidating its normative foundations. Respect is a reward for compliance with social norms that ensure the behavior of actors, to community expectations [1]. N. Luman attaches great importance to respect, which defines morality as "the designation of conditions under which individuals can or cannot respect themselves and others." [2]. According to the German sociologist, "respect should be understood 